\title{
THE USE OF MALAY MODALITIES IN ABSTRACTS OF PROCEDA SOCIAL AND BEHAVIORAL SCIENCES JOURNALS
}

\author{
Mirsa Umiyati dan Rika Purnama Sari \\ Universitas Warmadewa Bali \\ email: mirsa.umiyati2@gmail.com
}

\begin{abstract}
An abstract of research article should give information obviously. Modalities assist researcher to provide certain obvious information in an abstract. This study important to carry out to identify the types and functions of Malay modality used in abstracts of Proceda Social and Behavioral Sciences journal and examine the types of modality that are dominantly used in abstracts of Proceda Social and Behavioral Sciences journal. Qualitative and quantitative methods are the design of this study. Data of this study are abstracts from 18 articles of Proceda Social and Behavioral Sciences journal published by Elsevier. The data were analyzed using intralingual equivalent method by applying hubung banding menyamakan (HBS) technique. The results of the analysis are then presented using informal methods. Based on the results of the study, it can be concluded that there are four types of Malay modalities used in the abstracts of the Proceda Social and Behavioral Sciences journal, namely intentional, epistemic, deontic, and dynamic modalities. In addition, phrasal modals or periphrastic modals are found in the abstract in question. The dominant type of modality used in the abstract is intentional modality of $31 \%$. Furthermore, the Malay modality used in the abstract articles of the Proceda Social and Behavioral Sciences journal indicates the existence of this modal function in abstract construction. The functions of the modals are to inform the aims or objectives, focus, problem, background and gap, method, technique analysis, and suggestion of the research.
\end{abstract}

Keywords: abstract, malay, types of modalities

\section{PENGGUNAAN MODALITAS BAHASA MELAYU PADA ABSTRAK JURNAL PROCEDA SOCIAL AND BEHAVIORAL SCIENCES}

\begin{abstract}
Abstrak
Abstrak dalam artikel penelitian harus memberikan infomasi yang jelas. Modalitas dapat membantu peneliti untuk memberikaninformasi tertentu secara jelas dalam absrtrak. Penelitian ini bertujuan untuk mengidentifikasi jenis-jenis dan fungsi modalitas bahasa Melayu yang digunakan pada abstrak jurnal proceda social and behavioral sciences dan mengkaji jenis modalitas yang dominan digunakan pada abstrak jurnal proceda social and behavioral sciences. Metode qualitative dan quantitative adalah desain dari penelitian ini. Data penelitian ini adalah abstrak dari 18 artikel pada jurnal Proceda Social and Behavioral Sciences yang berbahasa melayu yang dipublikasikan oleh Elsevier. Dalam menganalisis data, digunakan metode padan intralingual dengan menerapkan teknik hubung banding menyamakan (HBS). Hasil
\end{abstract}


analisis kemudian disajikan dengan menggunakan metode informal. Berdasarkan hasil penelitian, dapat ditarik kesimpulan bahwa terdapat empat jenis modalitas bahasa Melayu yang digunakan pada abstrak jurnal Proceda Social and Behavioral Sciences, yaitu modalitas intensional, epistemic, deontic, dan dinamik. Selain itu ditemukan phrasal modals or periphrastic modals pada abstrak yang dimaksud. Jenis modalitas yang dominan digunakan dalam abstrak tersebut ialah modalitas intensional sebesar 31\%. Selanjutnya, modalitas bahasa Melayu yang digunakan pada abstrak artikel jurnal Proceda Social and Behavioral Sciences mengindikasikan adanya fungsi modal tersebut pada konstruksi abstrak.

Kata kunci: abstrak, bahasa melayu, jenis modalitas

\section{INTRODUCTION}

Issues, gaps, interests, phenomena and what is said Slameto (2016) as a result of contemplation or deep thinking to develop a particular field of science are the background of a scientific article. Thus, it is not surprising that so many scientific articles can be easily accessed and found on internet sites. It is very commonly known, scientific articles are many pages because it thoroughly examines issues, gaps, phenomena and even the development of a field of science with certain formulation of problems, aims, and methods.

Just one search of a particular scientific article shows a large number of similar scientific articles and take a lot of time to study the pages of the scientific article. With these problems, fortunately there is an abstract that summarizes the entirety of each scientific article. An abstract briefly describes what the article wants to convey (Nasution, 2017; Slameto, 2016). As short as possible, an abstract contains the problem, research objectives, methods, summary of results, conclusions and suggestions (Bhatia, 1993; Slameto, 2016; Swales, 1993).
This brief abstract is certainly inseparable from the assistance of modalities in systemic functional grammar which helps describe certain information in the abstract. This is not surprising, (Frawley, 2006) also once explained that the notion of modality has been used in different ways in the literature. If (Lycan, 1994) mentions that have to is an English modality as in I have to see you, Ira. As soon as possible and Halliday \& Matthiessen (2014) also mentioned must is an English modality as you must do that, thus mesti also be a modality in Malay that also helps describe information in the abstracts from scientific articles.

A modality or modal is the speaker's judgement, or request of the judgement of the listener, on the status of what is being said (Halliday, 1994; Halliday \& Matthiessen, 2014). More than that, a modality refers to any kind of speaker modification of a state of affairs, even including dimensions such as tense and aspect (Frawley, 2006). A modal adds information, such as possibility, necessity, or requests, to the verb that follows (Altenberg \& Vago, 2010). Emilia (2014) exemplified a kind of modal that gives an information of 
possibility as in Indonesia may have an opportunity to win.

Information in the form of possibilities, necessity, or requests is often found in every abstract of scientific articles as in the abstracts of scientific articles. The Malay modal of boleh sahaja describes the information of possibility in the abstract of the article. Other than that, information of requests is described in the modal of perlu.

According to Frawley (2006) modal that describe information in the form of a need or necessity and capacity are called dynamic modalities. Deontic modality is traditionally defined in terms of permission and obligation (Knežević \& Brdar, 2011). While, epistemic modality concerns an indication of the estimation. In other words, it expresses the degree of probability of the state of affairs. Deontic and epistemic modality types, then, which according to Halliday (1994) are called modalization and modulation. Probability and usuality belong to the modalization while obligation and inclination belong to the modulation (Eggins, 2004; Halliday, 1994).

Malay in the abstract of scientific articles sounds the same as Indonesian. There are many similarities between Malay and Indonesian (Erwany \& Rosliani, 2018). Thus, the types of Indonesian modalities that have been categorized into four types are the basis for researchers to classify the Malay modality types. The types of Indonesian modalities are studied by Alwi (1990) who classify Indonesian modalities into four types, namely intentional modalities that has meaning of inclination, expectation, invitations, and requests. Epistemic modality that has meaning of possibility, necessity, and certainty. Deontic modality that has meaning of permission and order. And dynamic modality that has meaning of ability.

The modalities mentioned do not stop being explained in the intentional, deontic, epistemic or dynamic types only. According to Alternberg \& Vago (2011) in (Emilia, 2014) that there are also some expressions that are similar to modals but consist of more than one word. These are called phrasal modals or periphrastic modals. Anew, from an abstract of scientific article gives an example of Malay phrasal modal or periphrastic modal, namely telah mampu.

A number of relevant studies that correspond to this current study have been studied with different results obtained. The first relevant research was examined by Erwany \& Rosliani (2018). This study reads about modality in the Malay Deli dialect. It found four types of modalities, namely the modality of intentionality, epistemic, deontic, and dynamic. In addition, there are modalites that are categorized as modalities but in Malay Deli dialect is not found because the modalites are likely derived from Javanese, such as the modalities use of menginginkan and mengingini can be exchanged to menghendaki. Other research on changes in the use of intentional modalities in Malay and Indonesian (Kurniasih, 2019). The study revealed that the use of modalities from the early 18th to the 19th centuries underwent a change. These changes can be widespread, but on the other hand narrows. Other than that, modalities in online media news texts have also been reviewed 
(Prihantoro \& Fitriani, 2015). The results of the study indicate that the type of intentional, epistemic, deontic, dynamic, and alastic modality are found in the online media news text.

Based on the background above, this study is very important to be built in order to identify the types and functions of Malay modalities used in abstracts of Proceda Social and Behavioral Sciences journals and examine the types of modalities that are dominantly used in abstracts of Proceda Social and Behavioral Sciences journals.

\section{METHOD}

The qualitative and quantitative method is design of this research (Creswell \& Creswell, 2018). The descriptive qualitative method is used to identify the function and the types of Malay Modalities used in abstract of Proceda Social and Behavioral Sciences Journal by describing the function and types into the understandable words. Not surprisingly, of course, quantitative methods used in this study. The quantitative method in this study is useful for measuring data through scientific calculations so that it can determine the frequency and percentage of the dominant modality used in abstract journals of Proceda Social and Behavioral Sciences, by displaying diagrams of the types of dominant modalities used in abstracts of the Proceda Social and Behavioral Sciences Journal.

This research data is abstract as much as 18 articles that taken from Proceda Social and Behavioral Sciences Journal which speak Malay with the search keyword 'pendidikan' on ScienceDirect.com, a journal website of various journals that may be obtained free or paid.

The data analysis method used in this current research is metode padan intralingual or intralingual equivalent method. This analysis method is done by comparing lingual elements in one language or several different languages. Thus, technique of hubung banding menyamakan (HBS) is the right technique when using this method, because this technique seeks similarities between the two things being compared (Mahsun, 2017), namely the modality of Malay and Indonesian. After analyzing, the results are then presented by using ordinary words, in addition to the technical terminology used in presenting the analysis results. The method of presenting the results of this analysis is called informal method (Zaim, 2014).

\section{RESULT AND DISCUSSION Result}

Abstracts of scientific articles in the Proceda Social and behavioral journal that use modalities of intentional, epistemic, deontic and dynamic totalling 18 abstracts. Each type of modality has its own meaning. Intentional modality consists of several meanings, namely inclination, expectation, invitations, and requests. Epistemic modalities consist of the meanings of possibilities, predictability, necessity and certainty. Deontic modalities consist of two meanings, namely command and permission. Finally, a dynamic modality that consists of only one meaning, namely capability. Furthermore, the number of uses of each type of modality in the abstract of Proceda Social and Behavioral Sciences Journal is described in several tables below. 
Table 1 Use of Intentional Modalities

\begin{tabular}{cllcl}
\hline \multicolumn{2}{c}{ Type of modality } & \multicolumn{1}{c}{ Modal } & Number & \multicolumn{1}{c}{ Description } \\
\hline & & akan & 13 & \\
Inclination & menetapkan & 1 & \\
Merkenaan & 1 & The use of intentional modality is 22 \\
Modality & & bertujuan & 6 & modals or 32\%. \\
& Expectation & diharapkan & 1 & \\
& Invitations & - & - & \\
& Requests & - & - & \\
\hline
\end{tabular}

Based on table 1 above, it can be seen that intentional modality of inclination is greater than the intentional modality of expectation. Meanwhile, intentional modality of invitations and requests are not found in any abstract in the Proceda Social and Behavioral Sciences journal.

Table 2 Use of Epistemic Modalities

\begin{tabular}{cllcl}
\hline \multicolumn{2}{c}{ Type of modality } & \multicolumn{1}{c}{ Modal } & Number & \multicolumn{1}{c}{ Description } \\
\hline & Possibilities & boleh sahaja & 1 & \\
& Predictability & sekiranya & 1 & \\
Epistemic & Necessity & perlu & 3 & The use of epistemic modalities is 17 \\
Modality & & memerlukan & 1 & modals or 25\%. \\
& & pasti & 9 & \\
& Certainty & sudah tentu & 1 & \\
& & telah & 1 & \\
\hline
\end{tabular}

From table 2 above, it is known that the dominant modality used is epistemic modality meaning of certainty with the most amount is in pasti modal, which is 9 clauses in several abstracts. As if followed by epistemic modality of necessity as many as 4 modals. The other kinds epistemic modality is found only 1 modal in a certain abstract.

Table 3 Use of Deontic Modalities

\begin{tabular}{cllcl}
\hline \multicolumn{2}{c}{ Type of modality } & \multicolumn{1}{c}{ Modal } & Number & \multicolumn{1}{c}{ Description } \\
\hline \multirow{4}{*}{$\begin{array}{c}\text { Deontic } \\
\text { Modalities }\end{array}$} & & Boleh & 6 & \\
& Command & Membolehkan & 1 & The use of deontic modality is 10 \\
& & Mestilah & 1 & modal or $15 \%$. \\
& Harus & 1 & \\
& sememangnya & 1 & \\
\hline
\end{tabular}


It can be seen from Table 3 above that the use of deontic modalities in the abstracts of the Proceda Social and Behavioral Science journal totals 10 modals from 18 abstracts with the description that deontic modality of permission is found more than deontic modality of command. If it calculated, there are 7 modals found in the abstracts mentioned. Whereas deontic modality of command is found in only 3 modals.

Table 4 Use of Dinamyc Modalities

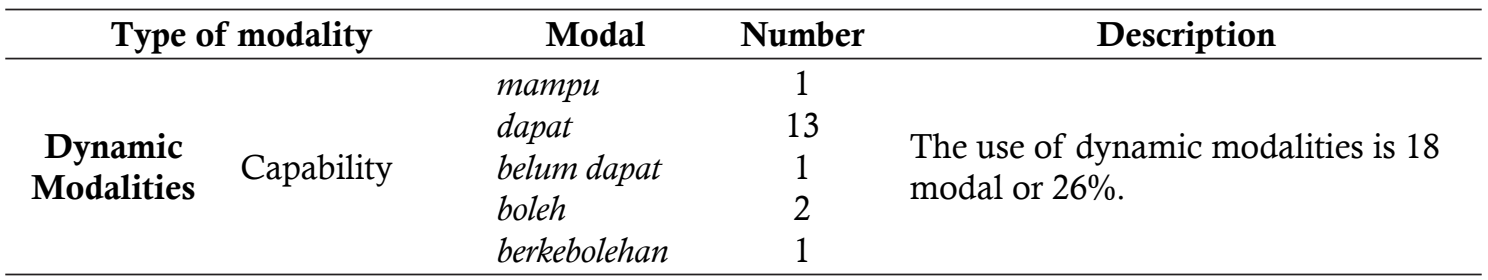

Based on table 4 above, it can be understood that the number of uses of dynamic modalities in the abstracts of the Proceda Social and Behavioral Science journal amounts to 18 modals. The dominant modal used is modal dapat as much as 13 modals in the abstract in question. While other modal which is far from this amount of modal, which is only 2 found is modal boleh and only 1 in modal mampu, belum dapat and berkebolehan.

Table 5 Use of Phrasal modals or periphrastic modals

\begin{tabular}{cccl}
\hline Type of modality & Modal & Number & \multicolumn{1}{c}{ Description } \\
\hline $\begin{array}{c}\text { Phrasal modals or } \\
\text { periphrastic modals }\end{array}$ & akan dapat & 1 & $\begin{array}{l}\text { The use of phrasal or periphrastic modal is } \\
\text { as much as } 1 \text { clause or } 1 \% .\end{array}$ \\
\hline
\end{tabular}

Table 5 above shows the use of phrasal modals or periphrastic modals in the abstract of Proceda Social and Behavioral Sciences Journal which only found 1 modal, that is modal of akan dapat from the 18 abstracts in question.

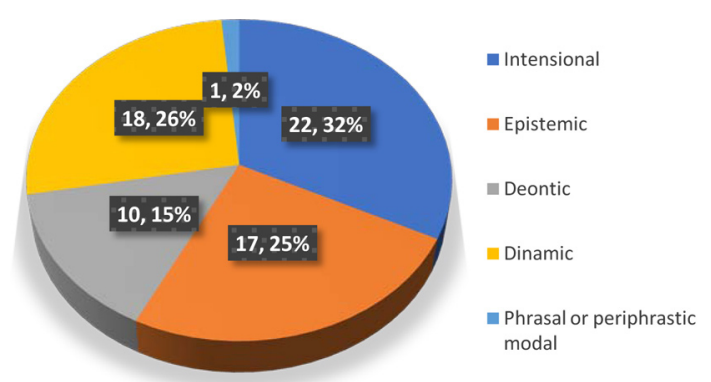

Figure 1. Types of Dominant Modalities Used in the Abstracts of Proceda Social and Behavioral Sciences Journal 
Based on the description of the types of modalities in the tables above, then in figure 1 it can be clearly seen that the dominant type of modality used in the abstract of Proceda Social and Behavioral Sciences Journal is intentional modality which amounts to 22 modals with a percentage of $32 \%$. The amount is followed by the type of dynamic modalities with 18 modals with a percentage of $26 \%$. The next type of modality that follows is epistemic with 17 modals with a percentage of $25 \%$. Furthermore, deontic modality with 10 modals with a percentage of $15 \%$. Finally, phrasal or periphrastic modals accounts for only 1 modal with a percentage of only $2 \%$.

\section{Discussion}

In this research, the type of modality based on the lingual form found is the phrasal modal or periphrastic modal. Meanwhile, the types of modality based on the meaning found are intentional, epistemic, deontic and dynamic. Adawiah (2017) argued the similar types of intentional, epistemic, deontic, and dynamic modality. As well as Priyastuti (2020) found the similar types of modality. Therefore, it can be said either modality used by Indonesian and American in political debate discourse (Adawiah, 2017) or English verbs modal used in speaking skill (Priyastuti, 2020) has similar types of Malay modality used in abstract of Proceda Social and Behavioral Science Journals. Nevertheless, although this study and Olaniyan \& Adeolu's (2015) study both examined modalities on the abstract. There are only two types of modalities found by them namely, intentional modality and deontic modality. In other words, modality in statement of objectives in Arts-based research article abstracts studied by Olaniyan \& Adeolu's (2015) does not inform possibilities, predictability, necessity, certainty and capabilities. Other than that, a huge distinction made by (Coates, 1983) divided modality into epistemic and root as well as ignored intentional modality. The root modality then divided into dynamic and deontic. Others by Hoye, (2005) divided modality into propositional modality which consist of epistemic and evidential and event modality which consist of deontic and dynamic.

\section{Intentional Modality}

Intentional modalities are modalities that provide information about inclination, expectation, invitations, and requests. Modal will used by researcher to express the inclination sense of modality (Adawiah, 2017). The use of intentional modality that has meaning of inclination in the abstract of Proceda Social and Behavioral Sciences Journal found in abstracts I, II, III, IV, V, and VI (see appendix).

In abstract I, five intentional modalities found that has meaning of inclination of modal akan, has function as a marker of aim of research, focus, and the problems discussed in the scientific article. Still with the same function, in abstract II, III as well as in abstract IV, the intentional modality has function on those abstracts as a marker of the aim of research in the scientific article. In abstract $\mathrm{V}$, the intentional modality has meaning of inclination found twice, that is, akan. It's just that the two modals have different functions in the abstract. The first modal serves 
as a marker of research objectives to be achieved, namely the driving factors that cause foreign students to master good Malay. Furthermore, the other modal function to indicate a data analysis technique will be used. In the abstract VI, intentional modality that has meaning of inclination is found as much as two modals. This modal has function to provide information about the background of the problems encountered in the study.

The use of intentional modality that has meaning of inclination of intention in the abstract of the Journal of Proceda Social and Behavioral Sciences found in abstracts IV, VII, VIII, IX, X and XI (see appendix) clearly function to explain the purpose of each research in each scientific article. The use of other intentional modality which has meaning of inclination of volition in the abstract of Proceda Social and Behavioral Sciences Journal is also found in abstract XII (see appendix). The use of intentional modality which has meaning of expectation in the abstract of Proceda Social and Behavioral Sciences Journal found in only abstract VI used to convey advice to certain parties.

Modal akan is the dominant modal used in the abstracts collected. On another research found that the modal most often used by students is will and can (Hykes, 2000; Priyastuti, 2020). Meanwhile, Hardjanto (2016) found that the type of modal that is often used is may in the five disciplines studied. In contrast to Ardiansah (2015), the epistemic modality was the dominant one found in students' hortatory exposition texts and Biber, Johansson, Leech, Conrad, \& Finegan (1999), the more common modality used in academic writing than in conversation was epistemic.

\section{Epistemic Modality}

Epistemic modality is a modality that provides information in the form of possibilities, predictability, necessity, and certainty. Besides that, marker of epistemic modality is expressing uncertainty in research articles (Vold, 2006), even in a study, the uncertainty are the high degree used in Archaeology articles (Rizomilioti, 2006), however the expressing uncertainty in question was not found in those abstract of research articles studied. It is clearly, epistemic modality informs possibilities, predictability, necessity, and certainty, therefore, as what Vázquez \& Giner (2008) argued that epistemic permits researchers to interpret the statements present in a research article in the manner in which the writer wants (Vázquez \& Giner, 2008).

The use of epistemic modalities of possibilities in abstracts of the Journal of Proceda Social and Behavioral Sciences found in modal boleh sahaja. Meanwhile, modal may is the modal used to indicate meaning of epistemic modal in English academic discourse (Hardjanto, 2016). Fløttum et al. in (Ngula, 2017) revealed that the typical and dominant marker of modality of epistemic used in research articles written by Ghanaian and International scholars is the modal may. This shows that the information which the Malaysian researcher wanted to convey was different from the information that the Ghanaian and International scholars wanted to convey even though they both used modalities to express it. 
In addition, the modal in the abstract II helps provide additional information about the background by explaining that both works that are either soothing text or beneficial text can be selected by the literary authors.

The use of epistemic modalities of certainty in abstracts of the Journal of Proceda Social and Behavioral Sciences found in the abstracts V, VIII, XI, XIII, XIV serve to provide certainty of the objectives of the study that are certain to be achieved. In the abstracts VII, epistemic modalities are found which serve to provide certainty information about the findings of the appropriate study. The epistemic modality in the abstract XII and XV provides information about the use of the study method, in other words the modal helps provide additional information related to the study method. The epistemic modality of certainty of modal sudah tentu in the abstract I and modal telah in the clause of abstract II. According to Grangé (2010) that sudah and telah are two markers indicated modalities. The use of epistemic modalities of necessity in the abstract of Proceda Social and Behavioral Sciences Journal found in abstracts VI, IX, XV, and XVI, have function to explain the background and gap of the study and to convey suggestions from the results of studies that have been conducted to certain parties. The use of epistemic modalities of predictability in abstracts of the Journal of Proceda Social and Behavioral Sciences is found in only abstract XIV, has a function as a conveyor of suggestions for encouragement and guidance of related individuals.

\section{Deontic Modalities}

Deontic modalities are modalities that provide information in the form of permission and commands. Suhadi (2011) voiced differently from that statement, the command on deontic modalities expressed into obligatory, advisable, and permissible such as must, should, may, and can. The use of deontic modalities of commands in abstracts of the Journal of Proceda Social and Behavioral Sciences found in abstract II 'mestilah' and 'harus' and XVII 'sememangnya'. Meanwhile the use of deontic modality of permission in which 'boleh' as the modal found in abstracts I, II, and IX. These modalities are clearly included in the deontic modality because they inform a permission and command. This contradicts PiquéAngordans, Posteguillo, \& AndreuBesó's (2002) mention that some modalities can be epistemic and deontic as well as Winiharti's (2012) said that both types can be express by a modal. Furthermore, the deontic modality in those abstracts is least than other modalities. As Ghivirigă \& Baciu (2015) stated the deontic modality is less frequent used in a corpus of Romanian scientific texts on economics.

\section{Dynamic Modalities}

Dynamic modalities are modalities that provide information in the form of capabilities. However, dynamic modality in English express volition, ability, and destiny (Kim (2017). As well as dynamic modality in English and Spanish inform the meanings of ability and tendency modals like can or could and semi-modals like be able to (Touriño, 2001). Meanwhile, dynamic modals in English and their Serbian TEs 
consist of dynamic possibility, dynamic necessity, and Volition (Radovanović, 2017).

The use of these modalities in the abstract Journal of Proceda Social and Behavioral Sciences are found in abstracts I, II, V, VI, VII, VIII, IX, X, XI, and XVII. The modals are mampu, dapat, boleh, belum dapat, berkebolehan. In addition, the use of phrasal modals or periphrastic modals in the abstract question is found in only abstract I, namely modal of akandapat. Modal boleh either in epistemic or dynamic modality can be clearly classified. Modal boleh in epistemic express a possibility and other express a capability. Therefore, the ambiguity of the distinction between epistemic and dynamic which is not clear as Kim (2017) concluded has been answered.

\section{CONCLUSION}

From the results of the above research, it can be concluded that there are four types of Malay modalities based on the meaning category used in the abstracts of the journal Proceda Social and Behavioral Sciences, namely intentional, epistemic, deontic, and dynamic modalities. Besides that, the type of modality found based on the lingual form category namely Phrasal modals or periphrastic modals in the abstract in question. In addition, the dominant type of modality used in the abstract is intentional modality.

Each Malay modality used in the abstracts of the journal article Proceda Social and Behavioral Sciences indicates the existence of this capital function in abstract construction. The modal 'akan' indicates markers rather than research goals, focus, and issues discussed in the scientific article.

Modal aims to indicate markers rather than the purpose of scientific articles created. The other modal provides information about the use of the study method used and there is also modal that serves to provide certainty information about the findings of the corresponding study. As well as capital that is expected to serve to convey advice to certain parties.

Nevertheless, it is also possible that an abstract can be arranged without using modality in it, of course, by using the appropriate word choice. So in the end, any abstract can be arranged briefly using either modality assistance or not using modality.

\section{ACKNOWLEDGEMENT}

We would like to express our deepest gratitude to the Universitas Warmadewa postgraduate program that has supported our research indirectly. We would also like to thank the researchers in the Proceda Social and Behavioral Sciences journal for the data we used in this study. A thank are also expressed to previous researchers, through their latest related research, were helped. We also express a very big thank to those around us who have made this article even better through the reviews provided.

\section{REFERENCES}

Adawiah, R. (2017). Modalities Used by Indonesian and American in Political Debate Discourse (A Comparative Studies). Jurnal Adabiyah, 17(1), 1-20.

Ajar, S., \& Ahmad, S. (2014). Kontrak sosial dalam pengajaran dan 
pembelajaran lisan: tinjauan terhadap perspektif pelajar. Procedia - Social and Behavioral Sciences, 134, 276-282. https://doi. org/10.1016/j.sbspro.2014.04.249

Altenberg, E., \& Vago, R. (2010). English Grammar: Understanding the Basic. https://doi.org/10.1192/ bjp.111.479.1009-a

Alwi, H. (1990). Modalitas dalam Bahasa Indonesia (Seri ILDEP). Yogyakarta: Penerbit Kanisius.

Ardiansah, D. (2015). An Analysis of Modality in Students' Hortatory Exposition Texts (Systemic Functional Grammar Perspective). Jurnal Pendidikan Bahasa Dan Sastra, 15(2), 136. https://doi. org/10.17509/bs_jpbsp.v15i2.1236

Asliza, N., \& Abd, N. (2014). Strategi komunikasi lisan secara formal dalamkalanganpelajarkejuruteraan. Procedia - Social and Behavioral Sciences, 134, 382-388. https://doi. org/10.1016/j.sbspro.2014.04.260

Baharudin, M. (2014). Pemerolehan dan penguasaan kecekapan berbahasa Melayu dalam kalangan pelajar asing di Universiti Sains Malaysia. 134, 270 275. https://doi.org/10.1016/j. sbspro.2014.04.248

Barin, S., \& Fikri, A. (2014). Analisis LeksikografiPerkataandalamAl-Qur'an Al-Karim: Antara Pisang dan Umm Ghailan. 134, 426-435. https://doi. org/10.1016/j.sbspro.2014.04.265

Bating, H. (2014). Karya Cerpen Kadazandusun dalam Konteks Kurikulum. Procedia - Social and Behavioral Sciences, 134, 350363. https://doi.org/10.1016/j. sbspro.2014.04.257
Bhatia, V. K. (1993). Analysing Genre: Language in Professional Settings. London: Longman.

Biber, D., Johansson, S., Leech, G., Conrad, S., \& Finegan, E. (1999). Longman Grammar of Spoken and Written English. Harlow: Pearson Education Limited.

Coates, J. (1983). The Semantics of The Modal Auxiliaries. London: Croom Helm.

Creswell, J. W., \& Creswell, J. D. (2018). Research Design: Qualitative, Quantitative, and Mixed Methods Approaches (5th ed.). California: SAGE Publications, Inc.

Darmia, S. (2014). Cabaran dan Reaksi Pelaksanaan Bahasa Kebangsaan dalam Bidang Pentadbiran dan Pendidikan di Malaysia , 19571966. Procedia - Social and Behavioral Sciences, 134, 305-315. https://doi. org/10.1016/j.sbspro.2014.04.253

Eggins, S. (2004). An Introduction to Systemic Functional Linguistics (2nd ed.). Retrieved from file:///C:/ Users/dell/Downloads/Suzanne Eggins - An Introduction to Systemic Functional Linguistics (2005, Continuum).pdf-downloaded library genesis

Emilia, E. (2014). Introducing Functional Grammar. Bandung: PT. Dunia Pustaka Jaya.

Erwany, L., \& Rosliani. (2018). Modalitas Dalam Bahasa Melayu Dialek Deli. Daun Lontar, 7(2), 2549.

Frawley, W. (2006). The Expression of Modality. Retrieved from http:// dnb.ddb.de.

Ghivirigă, T., \& Baciu, L. C. (2015). Between Epistemic and Deontic: The Use of Modal Verbs in a Corpus 
of Romanian Scientific Texts on Economics. SGEM2015 International Multidisciplinary Scientific Conferences on Social Sciences and Arts.

Grangé, P. (2010). Aspect and modality in Indonesian The case of sudah, telah, pernah, and sempat. Wacana, Journal of the Humanities of Indonesia, 12(2), 243. https://doi. org/10.17510/wjhi.v12i2.117

Halliday, M. A. . (1994). An Introduction to Functional Grammar (2nd ed.). Edward Arnold.

Halliday, M. A. ., \& Matthiessen, C. (2014). An Introduction to Functional Grammar (3rd ed.). Retrieved from https://www.functionalmedicine. org / files/library/Intro_ Functional_Medicine.pdf

Hardjanto, T. D. (2016). Hedging Through the Use of Modal Auxiliaries in English Academic Discourse. Jurnal Humaniora, 28(1), 37. https://doi.org/10.22146/ jh.v28i1.11412

Hasniza, C., \& Yusri, M. (2014). Kajian Penerokaan Buli Siber dalam Kalangan Pelajar UMT. Procedia - Social and Behavioral Sciences, 134, 323-329. https://doi. org/10.1016/j.sbspro.2014.04.255

Hoye, L. F. (2005). "You may think that; I couldn't possibly comment!"' Modality studies: Contemporary research and future directions. Part I. Journal of Pragmatics, 37, 1295-1321. https://doi.org/doi:10.1016/j. pragma.2005.01.004

Hykes, J. M. (2000). A comparison of the use of modal verbs in research articles by professionals and non-native speaking graduate students. Lowa State University.
Jaidi, N., Abdullah, Y., Tarasat, S., \& Kartika, S. (2014). Kesan penggunaan perisian iMindMap dalam penulisan karangan jenis rencana. Procedia - Social and Behavioral Sciences, 134, 389398. https://doi.org/10.1016/j. sbspro.2014.04.261

Kartika, S., Adikasuma, M., Tarasat, S., Bakar, A., \& Jaidi, N. (2014). Kesan bahan visual dalam penulisan karangan Bahasa Melayu. Procedia - Social and Behavioral Sciences, 134, 454-462. https://doi. org/10.1016/j.sbspro.2014.04.268

Kim, Y.-B. (2017). Modal Categories and Dynamic Modality in English. National Research Foundation of Korea, 17(4), 701727. https://doi.org/10.15738/ kjell.17.4.201712.701

Knežević, B., \& Brdar, I. (2011). Modals and Modality in Translation: A Case Study Based Approach. Jezikoslovlje, 12(2), 117-145.

Kurniasih, U. (2019). Perubahan Penggunaan Modalitas Intensional Dalam Bahasa Melayu Dan Bahasa Indonesia. DISASTRA, 1(1), 53-59.

Lycan, W. G. (1994). Modality and Meaning (Vol. 53). London: Kluwer Academic Publishers.

Mahsun. (2017). Metode Penelitian Bahasa: Tahapan, Strategi, Metode, dan Tekniknya (Edisi Keti). Depok: Rajawali Pers.

Mohamad, Z., \& Azma, Z. (2014). Sikap dan motivasi pelajar terhadap pembelajaran Bahasa Melayu. Procedia - Social and Behavioral Sciences, 134, 408-415. https://doi. org/10.1016/j.sbspro.2014.04.263

Muhamad, B., \& Ag, S. (2014). Analisis al-maf'uk al-mutlaq dalam surah- 
surah al-mufassal: Satu kajian kemukjizatan linguistik al-Quran. Procedia - Social and Behavioral Sciences, 134, 283-290. https://doi. org/10.1016/j.sbspro.2014.04.250

Muna, W., \& Subramaniam, V. (2014). Daya kreativiti kanak-kanak: Satu kajian kes. Procedia - Social and Behavioral Sciences, 134, 436445. https://doi.org/10.1016/j. sbspro.2014.04.266

Mustafa, R., Mohd, R., Sarbini-zin, M., \& Robiah, W. (2014). Amalan perubatan tradisional masyarakat Melayu Sarawak. Procedia - Social and Behavioral Sciences, 134, 316322. https://doi.org/10.1016/j. sbspro.2014.04.254

Nasution, M. K. M. (2017). Abstrak Suatu Karya Ilmiah. ResearchGate, (3), 2-5. https://doi.org/10.13140/ RG.2.2.14333.26086

Ngula, R. S. (2017). Epistemic modal verbs in research articles written by ghanaian and international scholars: A corpus-based study of three disciplines. Brno Studies in English, 43(2), 5-27. https://doi. org/10.5817/BSE2017-2-1

Olaniyan, K. K., \& Adeolu, A. (2015). Modality in Statement of Objectives in Arts-Based Research Article Abstracts. British Journal of English Linguistics, 3(1), 42-51. Retrieved from www.eajournals.org

Omar, A. (2014). Pemerkasaan Pemikiran Inventif di Negara Brunei Darussalam: Satu Percubaan Awal Pengajaran dan Pembelajarannya dalam Mata Pelajaran Bahasa Melayu. Procedia - Social and Behavioral Sciences, 134, 416425. https://doi.org/10.1016/j. sbspro.2014.04.264
Piqué-Angordans, J., Posteguillo, S., \& Andreu-Besó, J.-V. (2002). Epistemic and Deontic Modality: A Linguistic Indicator of Disciplinary Variation in Academic English. LSP \& Professional Communication, 2(2).

Prihantoro, E., \& Fitriani, D. R. (2015). Modalitas Dalam Teks Berita Media Online. Prosiding PESAT (Psikologi, Ekonomi, Sastra, Arsitektur \&Teknik Sipil) Universitas Gunadarma, 6, 1725.

Priyastuti, M. T. (2020). Penggunaan Modal Verbs Bahasa Inggris dalam Keterampilan berbicara. Journal of Language and Health, 1(1), 11-20.

Radovanović, A. (2017). Dynamic Modals-English and Serbian Contrasted. FACTA UNIVERSITATIS: Series Linguistics and Literature, 15(2), 273-285. https://doi.org/https://doi. org/10.22190/FULL1702273R

Rizomilioti, V. (2006). Exploring Epistemic Modality in Academic Discourse Using Corpora. In L. van Lier (Ed.), Information Technology in Languages for Specific Purposes: Issues and Prospects. New York: Springer Science+Business Media, Inc.

Slameto. (2016). Penulisan Artikel Ilmiah Hasil Penelitian Tindakan Kelas. Scholaria, 6(2), 46-57.

Suhadi, J. (2011). Epistemic Modality and Deontic Modality: Two Sides of a Coin. JULISA, 11(2), 156-179.

Swales, J. (1993). Genre Analysis: English in Academic \& Research Settings. Cambridge: Cambridge University Press.

Taisin, N. J. (2014). Genre puisi lisan tradisional Kadazandusun (sudawil): bahasa perlambangan dalam sudawil percintaan dan 
kasih sayang dari dimensi alam dan budaya.Procedia-SocialandBehavioral Sciences, 134, 291-297. https://doi. org/10.1016/j.sbspro.2014.04.251

Tarasat, S., \& Daud, A. (2014). Kesan penggunaan perisian asas membaca terhadap pencapaian membaca murid peringkat prasekolah. Procedia - Social and Behavioral Sciences, 134, 399-407. https://doi. org/10.1016/j.sbspro.2014.04.262

Touriño, A. V. (2001). Dynamic modality: English and Spanish contrasted. Studies in Contrastive Linguistics. Proceedings of the 2nd International Contrastive Linguistics Conference. Santiago: Santiago de Compostela.

Vázquez, I., \& Giner, D. (2008). Beyond Mood and Modality: Epistemic Modality Markers as Hedges in Research Articles. A Cross-Disciplinary Study. Revista Alicantina de Estudios Ingleses, 21, 171-190.

Vold, E. T. (2006). Epistemic modality markers in research articles: A crosslinguistic and cross-disciplinary study. International Journal of Applied Linguistics, 16(1), 61-87. https://doi.org/10.1111/j.14734192.2006.00106.x

Winiharti, M. (2012). The Difference Between Modal Verbsin Deontic and Epistemic Modality. HUMANIORA, 3(2), 532-539.

Zaim, M. (2014). Metode Penelitian Bahasa. Padang: FBS UNP Press Padang.

Zakaria, N. B. (2014). Peranan Pengarang Tradisi dalam Melahirkan Masyarakat Pemikir. Procedia - Social and Behavioral
Sciences, 134, 259-269. https://doi. org/10.1016/j.sbspro.2014.04.247

\section{APPENDIX}

1) Intentional

Abstract I

Kertas kerja ini akan membincangkan tentang perkembangan bahasa kebangsaan selepas Persekutuan Tanah Melayu mencapai kemerdekaan pada 31 Ogos 1957 sehingga tahun 1966. Perbincangan akan difokuskan terhadap usaha kerajaan dalam melaksanakan penggunaan bahasa kebangsaan khususnya dalam bidang pentadbiran dan Pendidikan (Darmia, 2014).

Hal ini kerana sesuatu yang lazim bagi sesebuah negara yang terdiri daripada masyarakat berbilang kaum akan berhadapan dengan masalah untuk mencapai perpaduan disebabkan perbezaan latar budaya, bahasa, kepercayaan dan lain-lain yang begitu ketara (Darmia, 2014).

Ini bermakna, bahasa kebangsaan bukan sahaja akan disaingi hebat oleh bahasa Inggeris tetapi juga perjuangan dan usaha untuk memastikan supaya bahasa kebangsaan terus berkembang maju akan berhadapan dengan pelbagai rintangan (Darmia, 2014).

Abstract II

Makalah ini akan membincangkan peranan pencerita dagang di bahagian kepengarangan Melayu tradisi berdasarkan model Koster mengenai Idea Buku (Zakaria, 2014).

\section{Abstract III}

Bertitik tolak daripada persoalan ini kertas kerja ini akan meninjau persepsi pelajar terhadap kelima-lima elemen kontrak sosial dalam pengajaran dan pembelajaran $(P \& P)$ lisan yang dipilih sebagai salah satu topik berkaitan dengan Perlembagaan Persekutuan (Ajar \& Ahmad, 2014). 


\section{Abstract IV}

kajian ini akan menampung kelompangan ini, iaitu bertujuan untuk mendokumentasikan amalan-amalan perubatan tradisional (Mustafa, Mohd, Sarbini-zin, \& Robiah, 2014).

Antara lain kajian ini juga akan mengupas aspek nilai dan pandangan mengenai kepentingan melestarikan amalan ini, khususnya daripada perspektif informan kajian dan budaya Melayu Sarawak (Mustafa et al., 2014).

Abstract V

Kajian ini akan mengenal pasti faktorfaktor pendorong yang menyebabkan pelajar asing ini boleh menguasai BahasaMelayuyangbaik(Baharudin, 2014).

Oleh yang demikian itu, satu analisis tahap kemahiran dan keperluan akan dibuat berdasarkan pemerolehan dan penguasaan kecekapan berbahasa Melayu dalam kalangan pelajar asing di USM (Baharudin, 2014).

\section{Abstract VI}

Dengannya, jika mereka berdepan dengan sesuatu masalah atau cabaran, individu yang mempunyai pemikiran jenis ini akan bersikap lebih positif selain mempunyai keupayaan untuk mengatasinya. Sebagaisalahsatuusaha Negara Brunei Darussalam untuk mempersiap rakyatnya agar menjadi tenaga kerja yang relevan dengan keperluan semasa dan akan datang, pengajarandanpemelajarankemahiran berfikir, antaranya Pemikiran Inventif, tidak ketinggalan diketengahkan dalam lanskap pendidikan tempatan (Omar, 2014).

Abstract I

Tempoh masa sepuluh tahun yang dipilih pula merupakan suatu tempoh yang menarik untuk dibincangkan kerana Perkara 152 (1) Perlembagaan Persekutuan 1957 telah menetapkan bahawa bahasa Melayu merupakan bahasa kebangsaan dan bahasa rasmi bagi Persekutuan (Darmia, 2014).

Abstract IV

kajian ini akan menampung kelompanganini, iaitubertujuan untuk mendokumentasikan amalan-amalan perubatan tradisional (Mustafa et al., 2014).

Abstract VII

Kajian penerokaan ini bertujuan untuk mengenalpasti jenis dan tingkahlaku yang berkaitan dengan buli siber dalam kalangan pelajar institusi pengajian tinggi (Hasniza \& Yusri, 2014).

Abstract VIII

Kajian ini bertujuan untuk mengenal pasti sama ada penggunaan bahan visual dalam pengajaran penulisaan karangan dapat meningkatkan pencapaian pelajar (Kartika, Adikasuma, Tarasat, Bakar, \& Jaidi, 2014).

Abstract IX

Jadi, kajian ini bertujuan untuk melihat kesan penggunaan perisian asas membaca terhadap pencapaian asas membaca murid-murid peringkat prasekolah (Tarasat \& Daud, 2014).

Abstract X

Kajian ini dilaksanakan adalah bertujuan untuk menilai tahap pencapaian pelajar dalam penulisan karangan jenis rencana (Jaidi, Abdullah, Tarasat, \& Kartika, 2014).

Abstract XI

Kajian "Daya Kreativiti Kanakkanak" adalah bertujuan untuk mengenal pasti instrumen atau bahan yang bersesuaian (Muna \& Subramaniam, 2014).

Abstract XII

Akhbar-akhbar berkenaan memiliki ruangan bahasa Kadazandusun untuk menyiarkan berita-berita dan karyakarya dalam bahasa Kadazandusun (Bating, 2014). 


\section{Abstract VI}

Diharapkan melalui kajian ini satu kefahaman yang rinci mengenai kerumitan pengajaran dan pemelajaran Pemikiran Inventif dalam kelas bahasa dapat diperoleh selain akhirnya ia dapat membantu mempersiap pihakpihak berkenaan dalam menyediakan satu program penyerapannya yang lebih serba lengkap dan lebih luas skopnya (Omar, 2014).

\section{2) Epistemic}

Abstract II

Pengarang sastera tradisi boleh sahaja memilih untuk melahirkan karya yang bersifat "soothing text" iaitu karya yang boleh melekakan, melalaikan, menghiburkan ataupun karya yang bersifat "benefecial text" (Zakaria, 2014).

Abstract V

Kajian ini akan mengenal pasti faktorfaktor pendorong yang menyebabkan pelajar asing ini boleh menguasai BahasaMelayuyangbaik(Baharudin, 2014).

\section{Abstract VIII}

Kajian ini bertujuan untuk mengenal pasti sama ada penggunaan bahan visual dalam pengajaran penulisaan karangan dapat meningkatkan pencapaian pelajar (Kartika et al., 2014).

Abstract XI

Kajian "Daya Kreativiti Kanakkanak" adalah bertujuan untuk mengenal pasti instrumen atau bahan yang bersesuaian (Muna \& Subramaniam, 2014).

Abstract XIII

Kajian ini bertujuan untuk mengenal pasti strategi komunikasi yang digunakan dalam kalangan pelajar jurusan kejuruteraan di Universiti Malaysia Perlis (UniMAP) ketika melakukan aktiviti kebahasaan di dalam kelas (Asliza \& Abd, 2014).
Objektif kertas kerja ini adalah untuk mengenal pasti jenis-jenis strategi komunikasi yang digunakan oleh responden di samping melihat persepsi mereka terhadap penggunaan bahasa Melayu sebagai medium perantaraan utama yang digunakan dalam sesuatu interaksi lisan yang dilakukan secara formal (Asliza \& Abd, 2014).

\section{Abstract XIV}

Kajian ini dijalankan untuk mengenal pasti sikap dan motivasi pelajar asing yang mempelajari bahasa Melayu sebagai bahasa ketiga di Universiti Teknologi Malaysia (UTM). Seramai 16 orang pelajar telah dipilih sebagai responden kajian untuk memenuhi objektif kajian ini iaitu untuk mengenal pasti sikap pelajar terhadap pembelajaran bahasa Melayu dan juga untuk mengetahui sejauh mana tahap motivasi pelajar terhadap pembelajaran Bahasa (Mohamad \& Azma, 2014).

\section{Abstract VII}

Dapatan kajian juga dapat mengenalpasti samada responden merupakan mangsa buli atau pun pembuli siber (Hasniza \& Yusri, 2014).

Abstract XII

Proses pembacaan dilakukan untuk mengenalpastielemenideologi, konvensi sastera dan budaya. Penganalisisan data dijalankan dengan menggunakan kaedah tipologi (Bating, 2014).

\section{Abstract XV}

Andaian mengenai struktur kognitif dan struktur pengamatan organisasi manusia juga berkait rapat dengan penggunaan bahasa perlambangan yang dikenal pasti turut hadir dalam sudawil percintaan dan kasih sayang (Taisin, 2014).

Abstract I

Namun begitu, sudah tentu terdapat cabaran dan reaksi yang terpaksa dihadapi dan ditangani dalam usaha 
untuk melaksanakan pengembangan bahasa kebangsaan daripada pihakpihak yang kurang berpuas hati khususnya orang bukan Melayu (Darmia, 2014).

Abstract II

Walaupun zaman telah berubah, tetapi lipatan sejarah harus dibuka, diingati, dihayati dan dipelajarisupaya manusia pada hari ini boleh mengulang zaman kegemilangan Melayu dahulu melalui formula yang telah tersedia ada dalam teksteks sastera sejarah. Ia juga wajar dihayati supaya manusia kini tidak mengulang kembali kesilapan yang boleh menghancurkan bangsa sendiri (Zakaria, 2014).

\section{Abstract VI}

Pemikiran Inventif tersenarai sebagai salah sebuah kemahiran Abad Ke21 yang perlu ada pada setiap warga dunia abad ini baik dalam dunia pekerjaan mahupun dalam bidang pelajaran (Omar, 2014).

Abstract IX

Membaca merupakan satu kemahiran asas yang sangat penting dan perlu dikuasai oleh murid-murid bagi membolehkan mereka mengikuti dan menguasai mata-mata pelajaran yang lain seperti Sains, Matematik dan lainlain (Tarasat \& Daud, 2014).

\section{Abstract XV}

Ia perlu untuk memberi kefahaman kepada masyarakat pendukungnya agar komunikasi lebih berkesan (Taisin, 2014).

\section{Abstract XVI}

Kepelbagaian variasi istilah yang terdapat di dalam Al-Qur'an Al-Karim memerlukan kepada penjelasan yang terperinci khususnya kepada penutur kedua Bahasa ini (Barin \& Fikri, 2014).

\section{Abstract XIV}

Keseluruhannya, pelajar asing mempunyai sikap yang positif dan motivasiyang tinggi untukmempelajari bahasa Melayu sekiranya mendapat dorongan dan panduan daripada individu berkaitan (Mohamad \& Azma, 2014).

\section{3) Deontic}

Abstract II

Berdasarkan kesedaran diri sastera Melayu tradisi, seseorang pengarang itu berfungsi berdasarkan peranan penceritaannya yang mana setiap karya yang dihasilkan mestilah berlandaskan kepada kesedaran mereka tentang sistem sastera Melayu tradisi (Zakaria, 2014).

Walaupun zaman telah berubah, tetapi lipatan sejarah harus dibuka, diingati, dihayati dan dipelajarisupaya manusia pada hari ini boleh mengulang zaman kegemilangan Melayu dahulu melalui formula yang telah tersedia ada dalam teksteks sastera sejarah (Zakaria, 2014).

Abstract XVII

terdapat juga kesignifikanan penggunaan al-Mafcul al-Mutlaq dalam surahsurah al-Mufassal dalam al-Quran yang dapat membuktikan bahawa skop kemukjizatan linguistik al-Quran dapat diperhati dan diteliti dalam sistem-sistem yang lebih kecil seperti sistem fonologi, morfologi dan sintaksisnya yang mendasari pembentukan dan kewujudan unsurunsur wacana dan primasastera alQuran yang sememangnya menjadi icjaz yang mencabar kelemahan dan kekurangan setiap yang mencabarnya dalam alam linguistic (Muhamad \& Ag, 2014).

Abstract I

Tetapi dalam perlembagaan itu juga telah disebut bahawa bahasa Melayu dan bahasa Inggeris bersama-sama boleh digunakandalam tempohsepuluh tahun tersebut (Darmia, 2014). 


\section{Abstract II}

Dalam sistem sastera Melayu tradisi, makna kepengarangan itu boleh dibezakan dengan peranan pencerita (Zakaria, 2014).

Pengarang sastera tradisi boleh sahaja memilih untuk melahirkan karya yang bersifat "soothing text" iaitu karya yang boleh melekakan, melalaikan, menghiburkan ataupun karya yang bersifat "benefecial text" (Zakaria, 2014).

Penuh di dalamnya rakaman peristiwa yang boleh menjadi panduan dan pedoman untuk masyarakat kini (Zakaria, 2014).

Walaupun zaman telah berubah, tetapi lipatan sejarah harus dibuka, diingati, dihayati dan dipelajarisupaya manusia pada hari ini boleh mengulang zaman kegemilangan Melayu dahulu melalui formula yang telah tersedia ada dalam teksteks sastera sejarah. Ia juga wajar dihayati supaya manusia kini tidak mengulang kembali kesilapan yang boleh menghancurkan bangsa sendiri (Zakaria, 2014).

\section{Abstract IX}

Membaca merupakan satu kemahiran asas yang sangat penting dan perlu dikuasai oleh murid-murid bagi membolehkan mereka mengikuti dan menguasai mata-mata pelajaran yang lain seperti Sains, Matematik dan lainlain (Tarasat \& Daud, 2014).

\section{4) Dinamic}

\section{Abstract I}

Namun, setelah pelbagai usaha giat dilaksanakan kerajaan akhirnya ia berhasil apabila penggunaan bahasa kebangsaan bukan sahaja mula meluas digunakan dalam bidang pentadbiran kerajaan tetapi juga dilihat telah mampu menjadi medium untuk menyebarkan ilmu pengetahuan sehingga ke hari ini (Darmia, 2014).

\section{Abstract II}

karya yang dapat mendidik akal, minda dan jiwa pembaca serta tidak bersifat melalaikan atau penuh nilainilai hiburan semata-mata (Zakaria, 2014).

Abstract V

Malah, tidaklah menghairankan kerana ada dalam kalangan mereka ini boleh bertutur dengan fasih dalam masa yang singkat (Baharudin, 2014).

Kajian ini akan mengenal pasti faktorfaktor pendorong yang menyebabkan pelajar asing ini boleh menguasai BahasaMelayuyangbaik(Baharudin, 2014).

Abstract VI

Diharapkan melalui kajian ini satu kefahaman yang rinci mengenai kerumitan pengajaran dan pemelajaran Pemikiran Inventif dalam kelas bahasa dapat diperoleh selain akhirnya ia dapat membantu mempersiap pihakpihak berkenaan dalam menyediakan satu program penyerapannya yang lebih serba lengkap dan lebih luas skopnya (Omar, 2014).

\section{Abstract VII}

Dapatan kajian juga dapat mengenalpasti samada responden merupakan mangsa buli atau pun pembuli siber (Hasniza \& Yusri, 2014).

Abstract VIII

Kajian ini bertujuan untuk mengenal pasti sama ada penggunaan bahan visual dalam pengajaran penulisaan karangan dapat meningkatkan pencapaian pelajar (Kartika et al., 2014).

Abstract IX

Walau bagaimanapun, hasil daripada kajian-kajian yang dijalankan menunjukkan bahawa kebanyakan murid di sekolah rendah masih belum dapat menguasai kemahiran membaca (Tarasat \& Daud, 2014). 


\section{Abstract X}

Dapatan kajian juga membuktikan bahawa penggunaan iMindMap bukan sahaja dapat meningkatkan pencapaian pelajar secara keseluruhan malah dalam aspek isi, bahasa dan teknik karangan (Jaidi et al., 2014).

\section{Abstract XI}

Instrumen lagu dan permainan yang menghasilkan penceritaan menunjukkan kanak-kanak pada tahap concrete operational yang mana kanak-kanak berkebolehan berfikir secara kritis dan kreatif dalam teori pertumbuhan kognisi oleh Jean Piaget (Muna \& Subramaniam, 2014).

\section{Abstract XVII}

dan terdapat juga kesignifikanan penggunaan al-Mafcul al-Mutlaq dalam surahsurah al-Mufassal dalam al-Quran yang dapat membuktikan bahawa skop kemukjizatan linguistik al-Quran dapat diperhati dan diteliti dalam sistem-sistem yang lebih kecil (Muhamad \& Ag, 2014).
Dimensi agama dapat dijelaskan melalui penglibatan al-Quran yang mendasari kajian ini. Sementara dimensi linguistik dapat dikesan melalui pengaplikasian bahasa Arab yang merupakan medium al-Quran itu sendiri (Muhamad \& Ag, 2014).

terdapat juga kesignifikanan penggunaan al-Mafcul al-Mutlaq dalam surahsurah al-Mufassal dalam al-Quran yang dapat membuktikan bahawa skop kemukjizatan linguistik al-Quran dapat diperhati dan diteliti dalam sistem-sistem yang lebih kecil (Muhamad \& Ag, 2014).

Dimensi agama dapat dijelaskan melalui penglibatan al-Quran yang mendasari kajian ini. Sementara dimensi linguistik dapat dikesan melalui pengaplikasian bahasa Arab yang merupakan medium al-Quran itu sendiri (Muhamad \& Ag, 2014).

Abstract I

Oleh itu, menyedari kepentingan perpaduan dalam memastikan pembangunan negara maka bahasa Melayu difikirkan salah satu medium yang akan dapat mencapai perpaduan tersebut (Darmia, 2014). 